\title{
Serum levels of creatine phosphokinase
}

\author{
P. D. GRIFFITHS
}

From the Department of Clinical Pathology, Guy's Hospital, London

SYNOPSIS Increasing interest in serum enzyme levels in various conditions has led to recognition of the value of the estimation of creatine phosphokinase activity in muscular disorders. Interpretation of the results obtained has been hampered by the lack of adequate information about the 'normas range'. Data for the normal levels of creatine phosphokinase in cord blood, children, and adults are presented.

Although the existence of creatine phosphokinase has been known for nearly 30 years (Lohmann, 1934), it is only in the last three or four years that any attention has been paid to its potential value as a diagnostic aid in clinical medicine. The enzyme is present in high concentrations in skeletal and cardiac muscle and to a lesser extent in brain tissue, but is only found in relatively small concentrations in other tissues (Colombo, Richterich, and Rossi, 1962). Study of other enzymes, notably serum glutamic oxaloacetic transaminase (LaDue, Wróblewski, and Karmen, 1954; Thomson, Leyburn, and Walton 1960; and many other authors), lactate dehydrogenase (White, 1956; Dreyfus, Schapira, and Schapira, 1958), and aldolase (Sibley and Lehninger, 1949; Volk, Lesner, Aronson, and Lew, 1956; Dreyfus, et al., 1958) frequently revealed high serum levels following myocardial infarction and in patients with a muscular dystrophy. In the light of these findings, it was not very surprising that increased levels of creatine phosphokinase have also been found in these conditions (Ebashi, Toyokura, and Momoi, 1959; Dreyfus, Schapira, Resnais, and Sčebat, 1960; Forster and Escher, 1961). A less expected observation was the high level that occurs in about $70 \%$ of hypothyroid patients (Graig and Ross, 1963; Griffiths, 1963). Interpretaton of results, due allowance having been made for variations in technique and reagents, ultimately depends on a knowledge of the levels present in an adequate number of normal subjects. This becomes vital in diagnostically difficult cases of myocardial infarction and in studies of muscular dystrophies, where detection of carriers or of potentially dystrophic patients can be valuable, circumstances in which the elevation of the enzyme level may be minimal. In the course of a larger study ${ }^{1}$,

${ }^{1}$ Thesis for M.D. to be submitted to London University.

Received for publication 24 April 1963. the creatine phosphokinase levels in the serum of more than 200 subjects, who fall outside the groups of diseases mentioned above, have been estimated.

\section{METHODS}

Creatine phosphokinase reversibly catalyses the reactio creatine phosphate + adenosine diphosphate $\rightleftharpoons$ creatine + adenosine triphosphate (Lehmann, 1935), and the enzymic activity can be estimated by studying either the forward (Ennor and Rosenberg, 1954) or the reverse reaction (Kuby, Noda, and Lardy, 1954). In this stud the forward reaction was employed, a modification of the method of Ennor and Rosenberg (1954) being used. The creatine liberated was estimated colorimetrically after carrying out a modified Barritt reaction (Ennor ane Stocken, 1948). The major departure from the technique of Ennor and Rosenberg lay in the incorporation cysteine hydrochloride into the incubation mixture. similar procedure has been described in detail by Hughẹs (1962).

\section{RESULTS}

The Table shows that the level of creatine phosphe kinase in cord blood is higher than that found serum during childhood and adult life. Even highe.

TABLE

N

CREATINE PHOSPHOKINASE LEVELS IN SUBJECTS WITT No MUSCLE DISEASE
Gex

\begin{tabular}{|c|c|c|c|c|}
\hline & & & & \\
\hline Newborn (cord blood) & $\begin{array}{l}\text { Male } \\
\text { Female }\end{array}$ & $\begin{array}{l}18 \\
21\end{array}$ & $\begin{array}{l}1 \cdot 8-8 \cdot 2^{x} \\
2 \cdot 0-6 \cdot 8\end{array}$ & 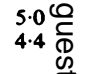 \\
\hline Children & $\begin{array}{l}\text { Male } \\
\text { Female }\end{array}$ & $\begin{array}{l}24 \\
21\end{array}$ & $\begin{array}{l}0.5-3.3 \\
0.2-3.4\end{array}$ & $\begin{array}{l}1.95 \\
1.700 \\
\end{array}$ \\
\hline Adults & $\begin{array}{l}\text { Male } \\
\text { Female }\end{array}$ & $\begin{array}{r}94 \\
104\end{array}$ & $\begin{array}{l}0.2-3.9 \\
0.2-3.7\end{array}$ & $\begin{array}{r}1.75 \overrightarrow{\mathrm{D}} \\
1.4 \stackrel{\mathrm{P}}{\overparen{D}}\end{array}$ \\
\hline
\end{tabular}

${ }^{1}$ Creatine phosphokinase activity expressed as $\mu \mathrm{M}$. creatine per $\mathrm{ml}$. per hour at $37^{\circ} \mathrm{C}$. 
values occur but these are almost invariably associated with known obstetric difficulties and/or birth trauma. The levels usually fall to those seen in adult life within a month of birth. The figures suggest that there may be a lower mean value in females than in males, but statistical analysis does not confirm this impression ( $P>0 \cdot 1$ in each of the three groups).

\section{DISCUSSION}

The higher levels of creatine phosphokinase found in cord blood are due most probably to the pronounced muscular activity associated with birth. Some haemolysis of the cord blood specimens is not uncommon, but as creatine phosphokinase activity is negligible in erythrocytes (Solvunuk, McRae, and Collier, 1956) this factor can be disregarded.

The levels reported in normal sera depend largely on the technique adopted for the estimation of the enzymic activity. For example, Tanzer and Gilvarg (1959), who utilized auxiliary reactions involving measurement of consumption of added dihydronicotinamide - adenine dinucleotide to estimate the rate of increase of adenosine diphosphate concentration, found no creatine phosphokinase activity in normal serum, whereas Forster and Escher (1961) using a similar technique found levels up to 1.5 (converted into international units). Ebashi et al. (1959) studied the reverse reaction and they too found negligible activity in normal sera. Dreyfus and Schapira (1961), using their modification of the technique of Ennor and Rosenberg (1954), reported normal values of 0.3 to $1.0 \mu \mathrm{M}$ creatine produced per ml. per hour at $37^{\circ} \mathrm{C}$. The more sensitive modification of this method by Hughes (1962) found values in $\mu \mathrm{M}$ creatine per $\mathrm{ml}$. per hour of up to 4.5 in males and 3.0 in females.

The observations of Hughes are of particular interest as he noted a highly significant difference in the means for the two sexes. He suggested the explanation of this might lie in the larger average muscle mass present in men. An alternative explanation might be related to the fact that there is an additional source of creatine phosphokinase in men, namely seminal fluid which possesses high enzymic activity (385-14,000 $\mu \mathrm{M}$ creatine per $\mathrm{ml}$. per hour), a fact which could be used for medico-legal purposes (Griffiths and Lehmann, 1964). Hughes' figures were based on 73 subjects, and although the present larger series does not lend support to his finding, caution must be exercised when interpreting values which are close to the upper limit of the normal range, particularly in the female relatives of Duchenne dystrophy patients, in whom increased levels have been reported (Dreyfus, Schapira, and Demos, 1960; Schapira, Dreyfus, Schapira, and Demos, 1960).

Apart from the conditions already mentioned, departures from the normal range occasionally occur in polymyositis, dermatomyositis, and burns. Hughes (1962) has also noted two cases of apparently secondary muscular disorders with raised levels, although this is not usual in such cases.

There is little doubt that estimation of creatine phosphokinase can be of considerable help both in the primary diseases of muscle and diagnosis of cardiac infarction. It is apparent that the present state of knowledge of creatine phosphokinase levels in serum and their significance is inadequate and further studies are urgently needed.

This work was partially supported by a grant from the Endowment Fund of Guy's Hospital Medical School. I am indebted to Dr. H. Lehmann and Dr. W. H. H. Merivale for help and encouragement.

\section{REFERENCES}

Colombo, J. P., Richterich, R., and Rossi, E. (1962). Klin. Wschr. 40, 37.

Dreyfus, J. C., and Schapira, G. (1961). Rev. franc. Étud. clin. biol., 6, 700.

- —, and Demos, J. (1960). Rev. franc. Étud. clin. biol., 5, 384.

_- Resnais, J., and Scebat, L. (1960). Ibid., 5, 386.

,-- , and Schapira, F. (1958). Ann. N.Y. Acad. Sci., 75, 235.

Ebashi, S., Toyokura, Y., and Momoi, H., and Sugita, H. (1959). J. Biochem. (Tokyo), 46, 103.

Ennor, A. H., and Rosenberg, H. (1954). Biochem. J., 57, 203.

, and Stocken, L. A. (1948). Ibid., 42, 557.

Forster, von G., and Escher, J. (1961). Helv. med. Acta, 28, 513.

Graig, F. A., and Ross, G. (1963). Metabolism, 12, 57.

Griffiths, P. D. (1963). Lancet, 1, 894.

- , and Lehmann, H. (1964). Medicine, Science and Law, in press.

Hughes, B. P. (1962). Clin. chim. Acta, 7, 597.

Kuby, S. A., Noda, L., and Lardy, H. A. (1954). J. biol. Chem., 210, 65.

LaDue, J. S., Wróblewski, F., and Karmen, A. (1954). Science, 120, 497.

Lehmann, H. (1935). Biochem. Z., 281, 271.

Lohmann, K. (1934). Ibid., 271, 264.

Schapira, F., Dreyfus, J. C., Schapira, G., and Demos, J. (1960). Rev. franc. Etud. clin. biol., 5, 990.

Sibley, J. A., and Lehninger, A. L. (1949). J. nat. Cancer Inst., 9, 303.

Solvunuk, P. F., McRae, S. C., and Collier, H. B. (1956). Canad. J. Biochem., 34, 481.

Tanzer, M. L., and Gilvarg, C. (1959). J. biol. Chem., 234, 3201.

Thomson, W. H. S., Leyburn, P., and Walton, J. N. (1960). Brit. med. J., 2, 1276.

Volk, B. W., Losner S., Aronson, S. M., and Lew, H. (1956). Amer. J. med. Sci., 232, 38

White, L. P. (1956). New Engl. J. Med., 255, 984. 